\title{
Copepods from Shore and Offshore Waters of Pakistan
}

Quddusi B. Kazmi

Marine Reference Collection and Resource Centre, University of Karachi, Karachi-75270, Pakistan., gbkazmi@mrcrc.ku.edu.pk

Follow this and additional works at: https://jmstt.ntou.edu.tw/journal

Part of the Marine Biology Commons

\section{Recommended Citation}

Kazmi, Quddusi B. (2004) "Copepods from Shore and Offshore Waters of Pakistan," Journal of Marine Science and Technology. Vol. 12: Iss. 4, Article 1.

DOI: $10.51400 / 2709-6998.2240$

Available at: https://jmstt.ntou.edu.tw/journal/vol12/iss4/1

This Research Article is brought to you for free and open access by Journal of Marine Science and Technology. It has been accepted for inclusion in Journal of Marine Science and Technology by an authorized editor of Journal of Marine Science and Technology. 


\section{Copepods from Shore and Offshore Waters of Pakistan}

\section{Acknowledgements}

I am grateful to my inspirational teacher Prof. N. M. Tirmizi, then Director of MRC, who obtained NASEER material from NIO, Karachi for me. Dr. Shahid Amjad, Director General NIO, Karachi is thanked for his assistance. This paper was read at 8th International conference on copepod (ICOC) 2002, Taiwan. It is with pleasure I express my gratitude to Dr. Ju-Shey Ho for suggesting my name for ICOC. Thanks are expressed to the organizers of ICOC for financial support that enabled me to join ICOC. Special thanks to Ms. Rene Chang of the conference secretariat for prompt answers and arrangements. Razia Naushaba of MRC helped in meiobenthic collection. These scientists helped in various ways: Dr. HansU-Dahms of Oldenburg, Germany for identification of the genus Parategastes and nauplii of Diosaccidae. Drs. Ju-Shey Ho, F.D. Ferrari, S. Vander Spoel, A.D. Mackinnon, C.K. Wong, T.C. Walter, H.B. Michael, G. A. Boxshall, and C. Razouls - who also allowed a free access to websites for confirmation of species, provided necessary literature and valuable suggestions on Muniza's thesis. Razia Naushaba of MRC helped in meiobenthic collection. Dr. Patsy McLaughlin of Shannon Point, Marine Centre, Western Washington, USA is acknowledged for Rindly improving the text. 


\title{
COPEPODS FROM SHORE AND OFFSHORE WATERS OF PAKISTAN
}

\author{
Quddusi B. Kazmi
}

Key words: copepods, checklist, Arabian Sea, Pakistan.

\begin{abstract}
This report is a history of copepodology based on the review of previously recorded species of copepods from Pakistan (Arabian Sea) by Pakistani workers and other contemporary surveys. The plankton samples studied are the epipelagic copepods collected during the Northern Arabian Sea Ecological and Environmental Research (NASEER) Cruise I (January 7-22, 1992) and Cruise IV (May 10-21, 1994). Some planktonic and phytal species obtained from a U.S. Office of Naval Research (ONR) project (1993-1995) on living resources in nearshore waters, and interstitial species obtained during a preliminary survey ONR (1998-2000) of the interstitial copepods carried out for the first time in Karachi intertidal regions (Bulleji and Sandspit) are also included.

Almost all the major copepod groups are represented in the above mentioned collections. In all 61 genera and 109 species have been reported. Out of these, 27 genera and 39 species have been collected from NASEER Cruises, some of them already reported (see Kazmi and Muniza, 1997-98) in the checklist only the species from stations located on Pakistan shelf are included. Acartia hamata Mori, 1937, Porcellidium viride (Philippi, 1890), Laophonte cornuta Philippi 1890 and Copilia mirabilis Dana, 1852 are recorded for the first time from the northern Arabian Sea. Abundance of species at all NASEER stations is also calculated. One phytal species Porcellidium viride (Philippi, 1840) is also a new record. The first investigation revealed that at least adults, subadults and larval stages of 12 families and 15 species are present in the interstitial copepod fauna. An attempt has been made to relate the diversity of species to the nature of the sand grains at Sandspit site.
\end{abstract}

\section{INTRODUCTION}

Bordering on the northern Arabian Sea, Pakistan has a sizeable maritime zone, influenced by atmospheric force of reversing monsoons. These result in the strong seasonal variability in its oceanographic conditions and thus the Arabian Sea appears to be an ideal place to understand link between climatic oscillations and community structure of zooplankton and biodiversity. A

Paper Submitted 07/03/03, Accepted 06/21/04. Author for Correspondence: Quddusi B. Kazmi. E-mail: gbkazmi@mrcrc.ku.edu.pk.

*Marine Reference Collection and Resource Centre, University of Karachi, Karachi-75270, Pakistan. multidisciplinary research theme, pertaining to biodiversity of the area, has been engaged by a number of international research activities in the Indian Ocean especially in the Arabian Sea. The Arabian Sea zooplankton is primarily comprised of copepods. However, studies on copepod abundance and distributions in the Indian Ocean have been based on total copepods found in zooplanktons (Kasturirangan et al., 1973) not individual species (with few exceptions) collections. The following presentation is an attempt to evaluate the existing knowledge of richness or scarcity of species in inshore and offshore waters of Pakistan.

\section{MATERIALS AND METHODS}

\section{Plankton samples}

The Northern Arabian Sea Ecological and Environmental Research (NASEER) programme was cosponsored by the National Institute of Oceanography, Pakistan (Karachi) and Oceanic Biological Programme of the US Office of Naval Research (ONR) programme.

The present NASEER plankton materials were assigned by the NIO to Marine Reference Collection \& Resource Centre (MRC), University of Karachi for study. The sampling procedure as communicated by the NIO tells that these samples were collected in horizontal zooplankton tows in the upper $5 \mathrm{~m}$ using a Bongo net of $60 \mathrm{~cm}$ diameter and 300 micron mesh size, the towing time was 10 minutes, towing direction was circular, the path horizontal and towing speed of net was 2-3 knot. A digital flowmeter was also used; however, it's reading was found to be unreliable on several occasions by NIO. The cruise was undertaken in the northern Arabian Sea $\left(22^{\circ} 51^{\prime}\right.$ to $24^{\circ} 58^{\prime} \mathrm{N}$ and $60^{\circ} 05^{\prime}$ to $\left.65^{\circ} 59^{\prime} \mathrm{E}\right)$ during January 7-22, 1992 and again in May 10-21, 1994 (Map 1). The cruise track totaled 1,200 nautical miles, included 62 ocean observation stations and 24 hrs time series stations (Sts. 8, 27, 33, 45, and 57).

The samples from NASEER 1 (Sts. 4, 8B, 8C, 8D $12,15,18,21,24,27 \mathrm{~A}, 27 \mathrm{~B}, 27 \mathrm{C}, 27 \mathrm{D}, 30,33 \mathrm{~A}, 33 \mathrm{~B}$, $33 \mathrm{C}, 33 \mathrm{D}, 45 \mathrm{~A}, 45 \mathrm{~B}, 45 \mathrm{C}, 45 \mathrm{D}, 49,53,57 \mathrm{~A}, 57 \mathrm{~B}, 57 \mathrm{C}$, 
57D, 60, and 62) of January were available for study. NASEER IV covered the same cruise track. Seven samples from Sts. 18, 27A, 27B, 33B, 33C, 33D, and 37 were available for analysis.

The samples were preserved in $5 \%$ buffered formalin, each sample measured $600 \mathrm{~mL}$. A subsample of $30 \mathrm{~mL}$ ( $5 \%$ of the whole) was separated for study.

Thirty-nine plankton samples were collected from Manora Channel (24․ $48^{\prime} \mathrm{N}$ and $\left.66^{\circ} 59^{\prime} \mathrm{E}\right)$ for Office of the Naval Research project during the years 1993-1995, using a Bongo net of 300 micron mesh size with horizontally attached flowmeter and a tow time of 10 minutes. These samples were collected twice a month, four samples from each station (Map 2, St. A and St. B). The surface and subsurface (10-12 m) samples were designated as: AI (surface sample), AII (subsurface sample), BI (subsurface sample), BII (surface sample). The samples were preserved in 5\% formalin and housed in the Marine Reference Collection and Resource Centre.

\section{Sampling and extracting meiofauna}

Forty sand samples for meiofauna were collected at low and high intertidal areas of two stations $7.5 \mathrm{~km}$ apart i.e. from Sandspit near Kakka village (245' $24^{\prime \prime} \mathrm{N}$, $66^{\circ} 54^{\prime} 24^{\prime \prime E}$ ) and Buleji (2450'12"N, 6649'12"E) (Map 3 ). To collect the sand sample a Yabi pump was used as a piston corer (dia $5 \mathrm{~cm}$ ). Sampling was done randomly over an area of 1 square meter quadrat; divided into 16 squares. Each portion of core was kept in a separate plastic bottle, filtered sea water was added to each bottle just above the sand level. The samples were brought to the MRC shore laboratory and preserved in $4 \%$ formaldehyde coloured with Rose Bengal.

\section{Sampling of phytal species}

The weeds were collected from the coast during years 1993-1995 and also eight samples (June to October, 1999) from the mudflats of upper tidal region of the mangroves, brought to the laboratory in polythene bags. There they were washed in tap water and filtered through a sieve (mesh size $1 \mathrm{~mm}$ ).

References to authorities of taxa are not included in the listed References of this paper.

\section{HISTORY OF PREVIOUS WORK}

The scientific papers on distribution and taxonomy of the extant copepods occurring in the western Indian Ocean (WIO) have increased tremendously, since the first work of Giesbrecht of 1889 on this group, particularly in the Arabian Sea, which is understood to possess many qualities that make it unique among the world

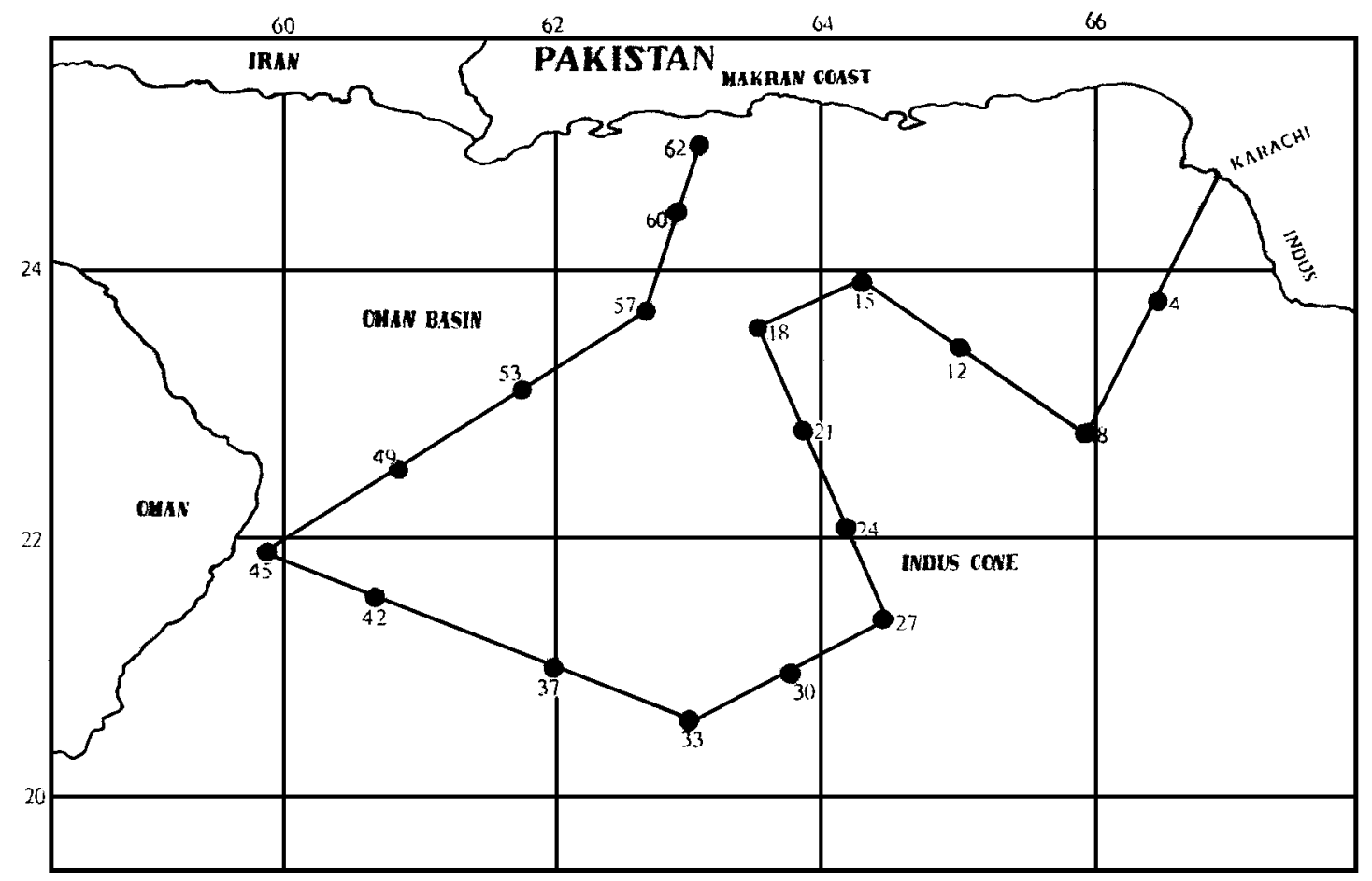

Map 1. Cruise track and stations (solid circles) of the Northern Arabian Sea Ecological and Environmental Research (NASEER) Programme (modified from Amjad et al., 1995). Solid circles and number show sampling stations. 
oceans (Ahmed et al., 1993). Some of the important works on copepods distribution and taxonomy in the WIO are: Pillai $(1967,1978)$, De Decker and Mombeck (1965), Grice and Hulsemann (1967), Kasturirangan et al. (1973), Fleminger and Hulsemann (1973), Stephen et al. (1992), Lawson (1977), Rajaram and Krishnaswamy (1980), Gajbhiye et al. (1991), Gopalakirshnan and Balachandran (1992), NIOP (1992-93), ARA-

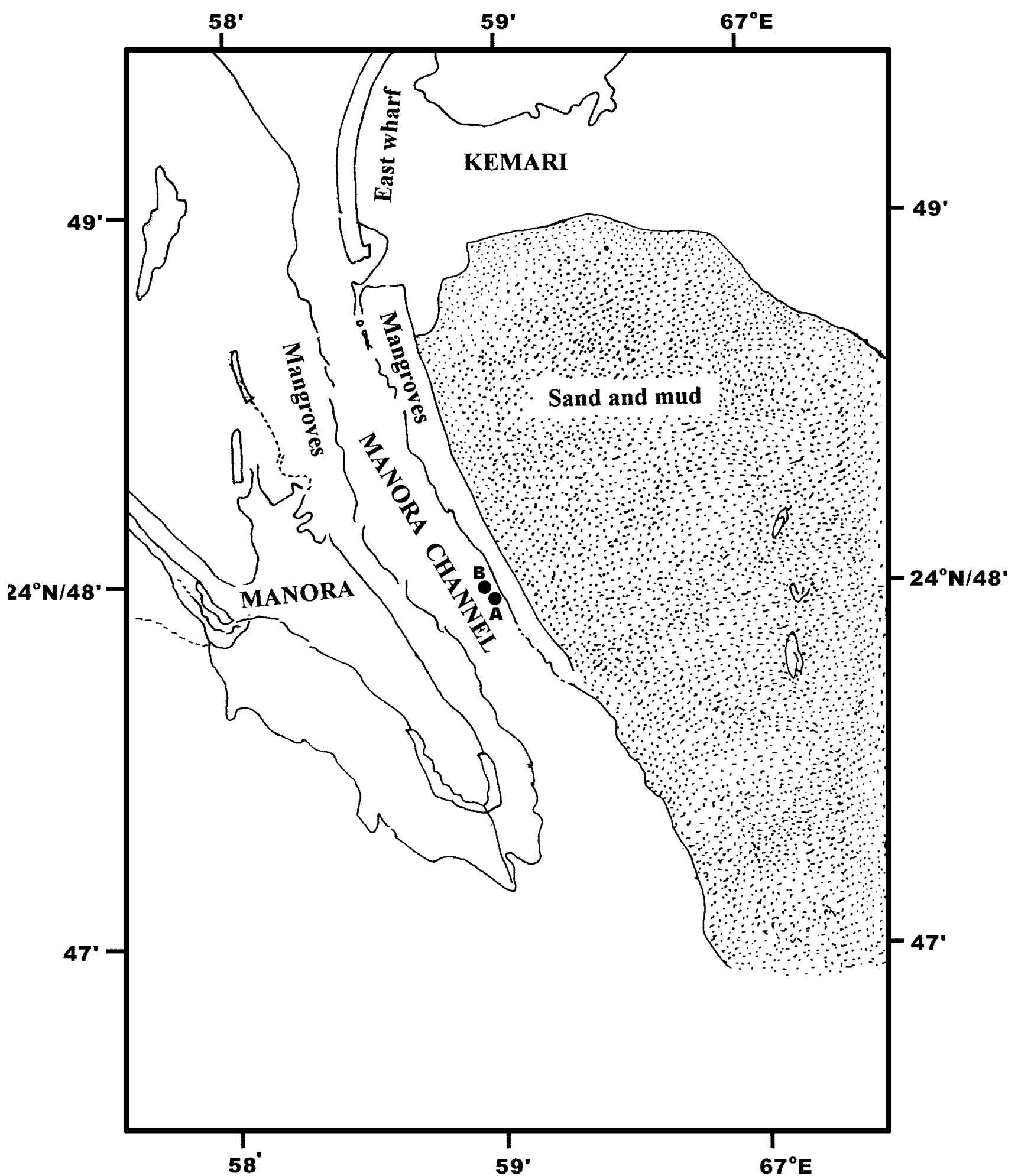

Map 2. Collection sites at Manora Channel. 
BESQUE (1994), Goswami (1994), Al-Yamani et al. (1995), and Razouls (1993, 1995, 1996, 1998). The history of the copepod taxonomic investigations in $\mathrm{Pa}-$ kistani waters (N. Arabian Sea) dates back to Bindra (1924). The area was then under the control of the British Government. Bindra's work was followed by the excellent contributions made by Sewell $(1947,1948)$ in the Indian Seas. His work of on John Murray Expedition and Investigator materials is an important reference for Pakistani copepodologists. British India was partitioned into Pakistan and India in 1947. After the political disturbance was over, work was resumed in Pakistan and reports on fresh water and marine copepods were published. The present paper summarises briefly the results of investigations into the marine copepod fauna of Pakistan as following. The early reports on zooplankton of Karachi coast published by the Marine Fisheries Department, Govt. of Pakistan and the Zoology Department of the Karachi University were by Ahmed (1951) and Ali and Arshad (1966) and then Haq (1968) published a paper on the variations in Undinula vulgaris (Dana, 1849). Gololobov and Grobov (1970) worked out the biomass, distribution and quantitative zooplank- ton composition in the Arabian Sea. Fazal-ur-Rehman (1973a) and Haq and Fazal-ur-Rehman (1973) contributed two new species: Pontella karachien-sis Fazal-urRehman, 1973 and Centropages karachien-sis Haq and Fazal-ur-Rehman, 1973. Fazal-ur-Rehman (1973b) also worked on variation in Tortanus forcipatus (Giesbrecht, 1889) and redescribed (1974) Pontella investigatoris (Sewell, 1912). Khan (1976) and Khan and Kamran (1975) erected two new species of monstril-loids, Cymbasoma williamsoni Khan, 1976 and Cym-basoma tirmizii Khan and Kamran, 1975. The occurrence of another species of Cymbasoma (C. rigidum Thompson, 1888) was reported by Khan et al. (1988). Khan worked on seasonal abundance of zooplankton (1974) and reported in 1977 a poecilostomatoid (Con-chyliurus maximus Reddiah, 1960). The major contributions to the systematics of Pakistani calanoids were by Ali Khan and Ali Khan from 1992-1998. The sources of their material were samples from the International Indian Ocean Expedition (IIOE) during its four cruises and the Cruise 1 of Dr. Fridtjof Nansen in the Arabian Sea.

The Zoological Survey of Pakistan also took part in publishing on copepopods where the families

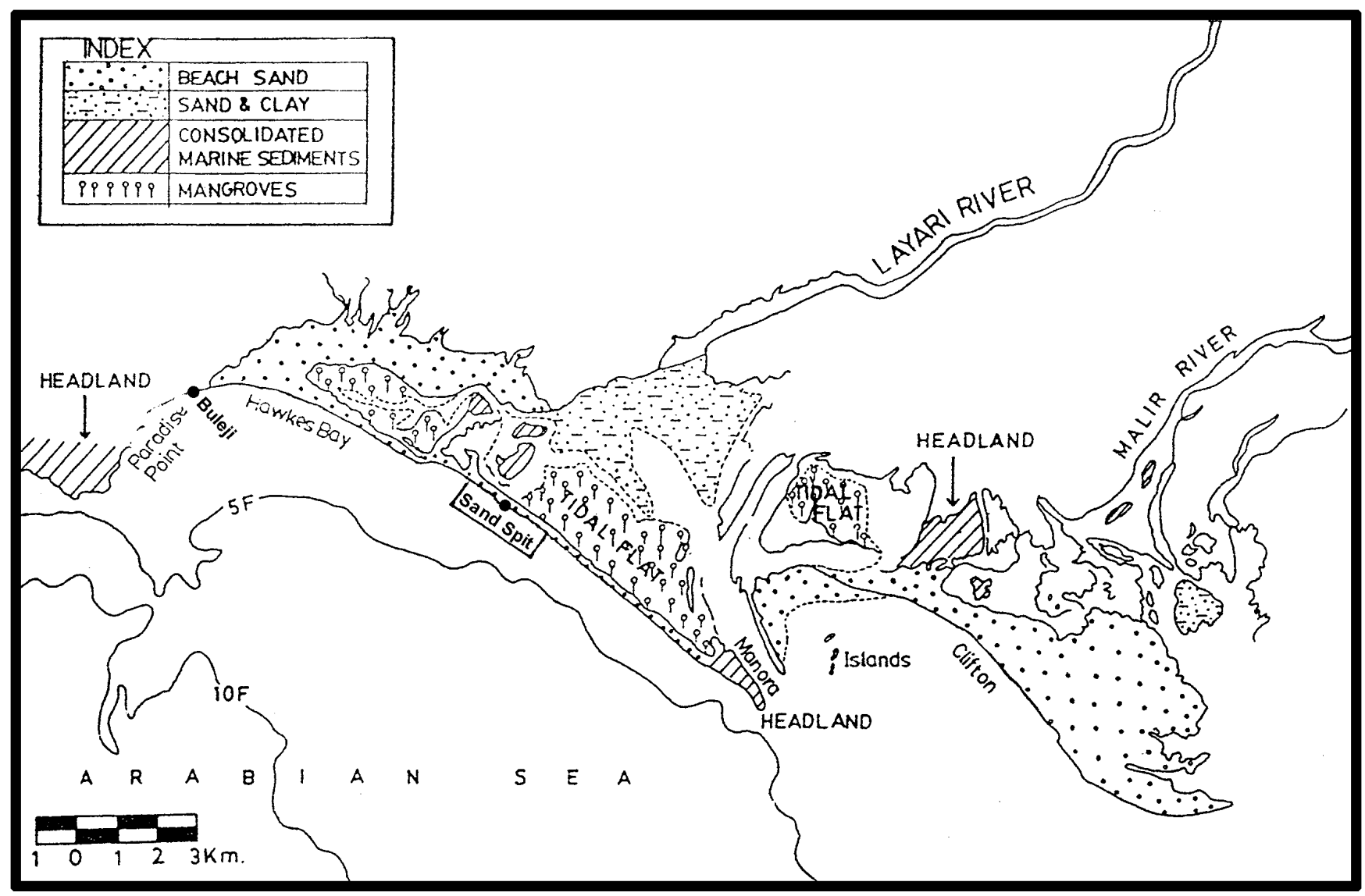

Map 3. Collection sites: Bulleji and Sandspit. 
Centropagidae (Centropages dorsispinatus Thompson and Scott, 1903, C. tenuiremis Thompson and Scott, 1903 and Isias tropica Sewell, 1932) and Temoridae (Temora dubia (Lubbock, 1856), Temora turbinata Dana, 1849) were dealt with by Ahmed et al. (1972); Pontella andersoni Sewell, 1912, P. investigatoris Sewell, 1912 and Tortanus forcipatus by Masihuzzaman (1973) whereas Niazi and Ahmed (1973a, b) worked on Siphonostomatoida, reporting Caligus diaphanous Nordman, 1832, Caligus robustus Bassett-Smith, 1898 (Caligidae) on Pampus argentus and Larnaeenicus hemirhamphi (Penneliidae) on Hemirhampheus xanthopterus. The zooplankton of mangrove areas was studied (Huda, 1993).

From NASEER samples analysis at MRC labs the results was the first report on the harpacticoids Miracia efferata Dana, 1852 (Miracidae) and Clytemnestra scutellata Dana, 1848 (Clymnestridae) from Pakistan (Kazmi and Muniza, 1994), a general survey on NASEER zooplankton by Kazmi et al. (1995), a paper on distribution of eucalanids (Muniza and Kazmi, 1995), another on abundance of poecilostomatoids (Kazmi and Muniza, 1995), another report on harpacticoids (Kazmi and Muniza, 1997a), and a broad overall summary of all the copepods of NASEER I and IV (Kazmi and Muniza, 1997b). Muniza was awarded M. Phil degree on her dissertation on NASEER copepods (1998). On the parasitic copepods Ali (1995) and Ghani and Ali (1996a, b) have worked.

The ONR research project (1993-95) in MRC on biodiversity also contributed to our knowledge on Pakistani nearshore copepods. The new record of the family Diossaccidae represented by Metamphiascopsis hirsutus (Thompson and Scott, 1903) from seaweeds and Caligus punctatus from near shore plankton were published by Sadiq (1995, 1996).

The results of meiobenthic studies (1998-2000) of intertidal sand were very encouraging, as the work was the first of its kind in Pakistan. Meiobenthic species have been reported by Naushaba and Kazmi (1998), Naushaba et al. (1998), Kazmi and Naushaba (2000), and Qureshi et al. (1999). The weed fauna was also reported upon by Ghani and Nawaz (2000).

\section{CHECK LIST}

Utilizing these reports and records, a checklist of Pakistani copepods has been prepared and is presented here. Ali Khan's 1998's list is included in its entirety although she gave it as a list of FAO Area 51, with no differentiation of shore and offshore species of the Pakistani coast and did not include all the IIOE R/V Anton Bruun bathypelagic species given by Grice and Hulsemann (1967). From NASEER samples, species only from station 62 on the leg nearer to our coast are included. The scheme of classification is that of Razouls (1993) and Martin and Davis (2001). Some 109 species from 61 genera and 39 families have now been recorded and this is obviously not the total picture. Preliminary identifications of other species are in preparation. Some old names are replaced by new names since some species listed in the earlier literature have been re-identified or identifications have been corrected.

The species listed have particular habitat preferences. Some show a degree of versatility and appear in several different habitat types. The habitats may be nearshore, offshore, psammonic, phytal, parasitic, detrital or associated with invertebrates.

\section{CHECKLIST OF MARINE COPEPODA OF PAKISTAN}

\begin{tabular}{|l|l|l|}
\hline & Source & Habitat \\
\hline Infraclass Neocopepoda Huys and Boxshall, 1991 & & \\
Superorder Gymnoplea Giesbrecht, 1882 & & \\
Order Calanoida Sars, 1903 & & Pelagic, offshore \\
Family Augaptilidae Sars, 1905 & Ali Khan and Ali Khan, 1984 & \\
Genus Augaptilus Giesbrecht, 1899 & & Offshore \\
Augaptilus longicaudatus (Claus, 1863) & Ali Khan and Ali Khan, 1984 & Offshore \\
Genus Euaugaptilus Sars, 1920 & Ali Khan and Ali Khan, 1984 & Offshore, bathypelagic \\
Euaugaptilus hecticus (Giesbrecht, 1892) & Grice and Hulsemann, 1967 & Offshore, bathypelagic \\
Euaugaptilus latifrons (Sars, 1907) & Grice and Hulsemann, 1967 & Offshore \\
$\begin{array}{l}\text { Euaugaptilus nodifrons (Sars, 1905) } \\
\text { Haloptilus } \text { longicornis (Claus, 1863) }\end{array}$ & Saraladevi, 1977 & Offshore, bathypelagic \\
Haloptilus paralongicirrus Park, 1970 & Ali Khan and Ali Khan, 1984 \\
Genus Pachyptilus Sars, 1920 & & \\
$\begin{array}{l}\text { Pachyptilus pacificus Johnson, 1936 } \\
\text { Family Heterorhabdidae Sars, 1902 }\end{array}$ & & \\
Genus Heterostylites Sars, 1920 & & \\
\hline
\end{tabular}




\begin{tabular}{|c|c|c|}
\hline Heterostylites longicornis (Giesbrecht, 1893) & Ali Khan, 1993b & Offshore, deep sea \\
\hline Genus Mesorhabdus Sars, 1905 & & \\
\hline Mesorhabdus angustus Sars, 1907 & Ali Khan, 1993b & Offshore, deep sea \\
\hline Family Lucicutiidae Sars, 1902 & & \\
\hline Genus Lucicutia Giesbrecht, 1889 & & \\
\hline Lucicutia clausi (Giesbrecht, 1889) & Ali Khan and Ali Khan, 1982 & Bathypelagic \\
\hline Lucicutia curta Farran, 1905 & Grice and Hulsemann, 1967 & Bathypelagic \\
\hline Lucicutia flavicornis (Claus, 1863) & Gololobov and Grobov, 1970 & $\begin{array}{l}\text { Bathypelagic, inshore } \\
\text { shallow water }\end{array}$ \\
\hline Lucicutia gaussae Grice, 1963 & Ali Khan and Ali Khan, 1982 & $\begin{array}{l}\text { Bathypelagic, inshore } \\
\text { shallow water }\end{array}$ \\
\hline Lucicutia grandis (Giesbrecht, 1895) & Grice and Hulsemann, 1967 & $\begin{array}{l}\text { Bathypelagic, inshore } \\
\text { shallow water }\end{array}$ \\
\hline Lucicutia longicornis (Giesbrecht, 1889) & Grice and Hulsemann, 1967 & $\begin{array}{l}\text { Bathypelagic, inshore } \\
\text { shallow water }\end{array}$ \\
\hline Lucicutia polaris Brodsky, 1950 & Ali Khan and Ali Khan, 1982 & Bathypelagic, inshore \\
\hline Family Metridinidae Sars, 1902 emend. & & shallow water \\
\hline Dunn and Hulsemann, 1979 & & \\
\hline Genus Pleuromamma Giesbrecht, 1898 & & \\
\hline Pleuromamma indica Wolfenden, 1905 & $\begin{array}{l}\text { Grice and Hulsemann, } 1967, \\
\text { Kazmi and Muniza, } 1998\end{array}$ & $\begin{array}{l}\text { Epi-benthopelagic, } \\
\text { nearshore-Oceanic }\end{array}$ \\
\hline Genus Gaussia Wolfenden, 1905 & & \\
\hline $\begin{array}{l}\text { Gaussia swelli Saraswathy, } 1973 \\
\text { Family Nullosetigeridae Soh et al., } 1999\end{array}$ & Saraswathy, 1973 & Upper $200 \mathrm{~m}$ \\
\hline Genus Phyllopus Brady, 1883 & & \\
\hline $\begin{array}{l}\text { Phyllopus impar Farran, } 1908 \\
=\text { Nullosetigera bidentata (Brady, 1883) }\end{array}$ & Ali Khan, 1998 & Offshore \\
\hline Family Acartiidae Sars, 1900 & & \\
\hline Genus Acartia Dana, 1846 & & \\
\hline Acartia amboinensis Carl, 1907 & Haq et al., 1973 & $\begin{array}{l}\text { Nearshore, shelf } \\
\text { epipelagic }\end{array}$ \\
\hline Acartia hamata Mori, 1937 & $\begin{array}{l}\text { Muniza, } 1998 \\
\quad \text { (unpublished thesis). New record }\end{array}$ & Offshore \\
\hline Family Candaciidae Giesbrecht, 1893 & & \\
\hline Genus Candacia Dana, 1846 & & \\
\hline Candacia turberculata Wolfenden, 1905 & Ali Khan, 1995 & Offshore \\
\hline Candacia curta (Dana, 1849) & Ali Khan, 1995 & Offshore \\
\hline Genus Paracandacia Grice, 1963 & & \\
\hline Paracandacia truncata (Dana, 1849) & Ali Khan, 1995 & Offshore \\
\hline Family Centropagidae Giesbrecht, 1893 & & \\
\hline Genus Centropages Kroyer, 1848 & & \\
\hline Centropages dorsispinatus Thompson and Scott, 1903 & Ahmed et al., 1972 & Nearshore, creeks \\
\hline Centropages furcatus (Dana, 1849) & Ali Khan, 1998 & Offshore, shallow waters \\
\hline Centropages orsinii Giesbrecht, 1892 & Ali Khan, 1998 & Nearshore, offshore \\
\hline Centropages kroeyeri Giesbrecht, 1892 & Ali Khan, 1998 & Epipelagic \\
\hline Centropages tenuiremis Thompson and Scott, 1903 & Ahmed et al., 1972 & Nearshore, creeks \\
\hline $\begin{array}{l}\text { Centropages karachiensis Haq and } \\
\text { Fazal-ur-Rehman, } 1973\end{array}$ & Haq and Fazal-ur-Rehman, 1973 & Nearshore \\
\hline Genus Isias Boeck, 1864 & & \\
\hline Isias tropica Sewell, 1932 & Ahmed et al., 1972 & Nearshore \\
\hline Family Pontellidae Dana, 1852 & & \\
\hline Genus Calanopia Dana, 1852 & & \\
\hline Calanopia elleptica (Dana, 1849) & Ali Khan, 1998 & Coastal \\
\hline Calanopia minor A. Scott, 1902 & Ali Khan, 1998 & Coastal and oceanic \\
\hline Genus Labidocera Lubbock, 1853 & & \\
\hline Labidocera acuta Dana, 1849 & Ali Khan, 1998 & Offshore \\
\hline Labidocera pectinata Thompson and Scott, 1903 & Masihuzzaman, 1973 & Nearshore \\
\hline Labidocera minuta Giesbrecht, 1893 & Ali Khan, 1998 & Inshore, coastal \\
\hline Genus Pontella Dana, 1846 & & \\
\hline Pontella andersoni Sewell, 1912 & Masihuzzaman, 1973 & Nearshore \\
\hline Pontella investigatoris Sewell, 1912 & Masihuzzaman, 1973 & Inshore, nearshore \\
\hline
\end{tabular}


Pontella securifer Brady, 1883

Pontella karachiensis Fazal-ur-Rehman, 1973

Genus Pontellopsis Brady, 1883

Pontellopsis sp.

Family Pseudodiaptomidae Sars, 1902

Genus Pseudodiaptomus Herrick, 1884

Pseudodiaptomus serricaudatus J. Scott, 1894

Family Temoridae Giesbrecht, 1893

Genus Temora Baird, 1850

Temora discaudata Giesbrecht, 1889

Temora turbinata (Dana, 1849)

Temora dubia (Lubbock, 1856)

Genus Temoropia J. Scott, 1894

Temoropia mayumbaensis J. Scott, 1894

Family Tortanidae Sars, 1902

Genus Tortanus Giesbrecht, 1898

Tortanus (Tortanus) forcipatus (Giesbrecht, 1889)

Family Clausocalanidae Giesbrecht, 1893

Genus Clausocalanus Giesbrecht, 1888

Clausocalanus minor Sewell, 1929

Clausocalanus furcatus (Brady, 1883)

Clausocalanus arcuicornis (Dana, 1849)

Clausocalanus farrani Sewell, 1929

Family Euchaetidae Giesbrecht, 1893

Genus Euchaeta Phillipi, 1843

Euchaeta rimana Bradford, 1974

Euchaeta concinna Dana, 1849

Enchaeta murrayi, Sewell, 1948

Euchaeta marina (Prestandarea, 1833)

Euchaeta wolfendeni A. Scott, 1909

Family Scolecitrichidae Giesbrecht, 1893

Genus Pseudoamallothrix Sars, 1925

Pseudoamallothrix longispina (Schulz, 1991)

Genus Scaphocalanus Sars, 1900

Scaphocalanus magnus (Scott, 1894)

Scaphocalanus longifurca (Giesbrecht, 1888)

Genus Scolecithricella Sars, 1902

Scolecithricella paramarginata Schulz, 1991

Genus Scolecithrix Brady, 1883

Scolecithrix nicobarica Sewell, 1929

Scolecithrix ctenopus (Giesbrecht, 1888)

Genus Scottocalanus Sars, 1905

Scottocalanus sedatus Farran, 1936

Family Eucalanidae Giesbrecht, 1893

Genus Subeucalanus Geletin, 1976

Subeucalanus crassus (Giesbrecht, 1888)

Subeucalanus pileatus (Giesbrecht, 1888)

Subeucalanus subcrassus (Giesbrecht, 1888)

Subeucalanus subtenuis (Giesbrecht, 1888)

Subeucalanus mucronatus (Giesbrecht, 1888)

Genus Pareucalanus Geletin, 1976

Pareucalanus attenuatus (Dana, 1849)

Genus Rhincalanus Dana, 1853

Rhincalanus nasutus Giesbrecht, 1888

Rhincalanus cornutus (Dana, 1849)

Family Calanidae Dana, 1846
Fazal-ur-Rehman, 1974

Ali Khan, 1998

Fazal-ur-Rehman, 1973a

Huda, 1993

Ali Khan, 1998

Flemingere Hulsmann, 1973

Ahmed et al., 1972

Ahmed et al., 1972

Ali Khan, 1998

Masihuzzaman, 1973

Golobov and Grobov, 1970

Grice and Hulsemann, 1967

Haq et al., 1973

Haq et al., 1973

Ali Khan, 1998

Haq et al., 1973

Sewell, 1948

Haq et al., 1973

Haq et al., 1973

Ali Khan, 1998

Grice and Hulsemann, 1967

Ali Khan, 1998

Ali Khan, 1998

Grice and Hulsemann, 1967

Ali Khan, 1998

Ali Khan, 1998

Haq et al., 1973

Haq et al., 1973

Ali Khan, 1992

Gololobov and Grobov, 1970

Haq et al., 1973

Ali Khan, 1992

Haq et al., 1973,

Muniza and Kazmi, 1995

Sewell, 1947
Inshore, offshore

Nearshore

Coastal

Coastal, brackish

Nearshore-off shore

Nearshore, shelf, epipelagic

Nearshore

Offshore

Inshore, nearshore

Offshore

Offshore, bathypelagic

Shelf, epipelagic

Shelf

Offshore

Offshore, epipelagic

Epipelagic to

mesopelagic

Offshore

Nearshore, offshore

Bathypelagic

Offshore, bathypelagic

Bathypelagic

Offshore

Bathypelagic

Offshore

Offshore

Coastal shelf, epipelagic Coastal shelf, epipelagic

Coastal, bathypelagic

Coastal, shelf, epibathypelagic

Oceanic

Bathypelagic

Epi-bathypelagic, oceanic

Bathypelagic 
Genus Canthocalanus A. Scott, 1909

Canthocalanus pauper Giesbrecht, 1888

Genus Undinula A. Scott, 1909

Undinula vulgaris (Dana, 1849)

Family Paracalanidae Giesbrecht, 1893

Genus Acrocalanus Giesbrecht, 1888

Acrocalanus longicornis Giesbrecht, 1888

Acrocalanus monachus Giesbrecht, 1888

Acrocalanus gracilis Giesbrecht, 1888

Genus Paracalanus Boeck, 1864

Paracalanus aculeatus Giesbrecht, 1888

Genus Calocalanus Giesbrecht, 1888

Calocalanus pavo (Dana, 1849)

Order Harpacticoida Sars, 1903

Family Canuellidae Lang, 1944

Genus Scottolana Por, 1984

Scottolana longipes (Thompson and Scott, 1903)

Family Ectinosomatidae Sars, 1903

Genus Microsetella Brady and Robertson, 1873

Microsetella norvegica (Boeck, 1865)

Family Clytemnestridae A. Scott, 1909

Genus Clytemnestra Dana, 1847

Clytemnestra scutellata Dana, 1848

Family Porcellidiidae Boeck, 1865

Genus Porcellidium Sars, 1904

Porcellidium viride (Philippi, 1840)

Family Tisbidae stebbing, 1910

Genus Sacodiscus Wilson, 1926

Genus Sacodiscus Littoralis (Sars, 1904)

Family Tegastidae Sars, 1904

Genus Parategastes Sars, 1904

Parategastes sp.

Family Canthocamptidae Sars, 1906

Genus Bryocamptus Westwood, 1836

Bryocamptus sp. (Copepodid II)

Family Cylindropsyllidae Sars, 1909

Genus Arenopontia Kunz, 1837

Arenopontia indica Rao, 1967 (stage)

Family Diosaccidae Sars, 1906

Genus Metamphiascopsis Thompson and Scott, 1903

Metamphiascopsis hirsutus (Thompson and Scott, 1903)

Family Miraciidae Dana, 1846

Genus Miracia Dana, 1846

Miracia efferata Dana, 1852

Genus Macrostellata A. Scott, 1909

Macrostellata gracilis (Dana, 1847)

Famils Laophontidae Scott, 1905

Genus Laophonte Philippi, 1840

Laophonte cornuta Philippi, 1840

Order Poecilostomatoida Thorell, 1859

Family Chondracanthidae Milne Edwards, 1840

Genus Protochondracanthus Kirtisinghe, 1950

Protochondracanthus sp.

Family Clausidiidae Embleton, 1901

Genus Conchyliurus Bocquet and Stock, 1957

Conchyliurus maximus Reddiah, 1960

Family Corycaeidae Dana, 1852

Genus Corycaeus Dana, 1845

Corycaeus crassiusculus Dana, 1891
Grice and Hulsemann, 1967, Haq et al., 1973

Haq, 1968

Ali Khan, 1998

Ali Khan, 1998

Gololobov and Grobov, 1970

Gololobov and Grobov, 1970

Ali Khan, 1998

Kazmi and Naushaba, 2000

Kazmi and Naushaba, 2000

Kazmi and Muniza, 1994

New record

Tirmizi and Sadiq, 1995

Kazmi and Naushaba, 2000

Kazmi and Naushaba, 2000

Kazmi and Naushaba, 2000

Sadiq, 1996

Kazmi and Muniza, 1994

Sewell, 1948

New record

Ghani and Ali, 1996b

Khan, 1977

Haq et al., 1973
Bathypelagic, offshore, epipelagic

Nearshore, shallow water

Oceanic, surface

Offshore

Shelf

Shelf, epipelagic

Offshore, coastal

Psammonic

Offshore

Offshore, inshore, sand

Phytal

Phytal

Phytal

Psammonic

Psammonic

Phytal

Offshore, inshore

Coastal

Phytal

Parasitic

Parasitic

Shelf, epipelagic 
Corycaeus flaccus Giesbrecht, 1892

Family Oncaeidae Giesbrecht, 1893

Genus Oncaea Philippi, 1943

Oncaea media Giesbrecht, 1891

Oncaea conifera Giesbrecht, 1891

Oncaea vanusta Philippi, 1843

Family Sapphirinide Thorell, 1860

Genus Copilia Dana, 1849

Copilia mirabilis Dana, 1852

Genus Sapphirina Thompson, 1829

Sapphirina gemma Dana, 1849

Order Siphonostomatoida Thorell, 1859

Family Caligidae Burmeister, 1834

Genus Caligus Muller, 1785

Caligus punctatus Shiino, 1955

Caligus diaphanus Nordman, 1832

Caligus robustus Bassett. Smith, 1898

Genus Paralebion Wilson, 1911

Paralebion elongatus Wilson, 1911

Family Penneliidae Burmeister, 1834

Genus Lernaeenicus Le Sueur, 1824

Lernaeenicus hemirhamphi Kirtisinghe, 1933

Order Monstrilloida Sars, 1901

Family Monstrillidae Dana, 1849

Genus Cymbasoma Thompson, 1888

Cymbasoma williamsoni Khan, 1976

Cymbasoma tirmizii Khan and Kamran, 1975

Cymbasoma rigidum Thompson, 1888

Superorder Podoplea Giesbrecht, 1882

Order Misophrioida Gurney, 1933

Family Misophriidae Brady, 1878

Genus Benthomisophria Sars, 1909

Benthomisophria palliata Sars, 1909

Order Cyclopoida Burmeister, 1834

Family Oithonidae Dana, 1852

Genus Oithona Baird, 1843

Oithona plumifera Baird, 1843
Haq et al., 1973

Kazmi and Naushaba, 2000

Haq et al., 1973

Sewell, 1948

New record

Muniza, 1988 (unpublished thesis)

Sadiq, 1995

Niazi and Ahmed, 1973a

Niazi and Ahmed, 1973a

Ali, 1995

Niazi and Ahmed, 1973b,

Ghani and Ali, 1996a

Khan, 1976

Khan and Kamran, 1975

Khan et al., 1988

Ali Khan, 1993c

Haq et al., 1973
Shelf, epipelagic

Planktonic, associated

Epipelagic

Epiplagic-bathypelagic

Inshore

Coastal, inshore

Parasitic

Parasitic

Parasitic

Parasitic

Parasitic

Endoparasitic naupliar and planktonic adult

Endoparasitic naupliar and planktonic adult

Endoparasitic naupliar and planktonic adult

Offshore, bathypelagic

Shelf, epipelagic

\section{GENERAL FEATURES OF MATERIALS DISCUSSED}

\section{Shelf species}

In the northwestern sector where high productivity was recorded (Gololobov and Grobov, 1970) the predominant organisms were the Calanidae, having different generic compositions from the previous check lists.

\section{NASEER samples}

Numerically, copepods were by far the most dominant group in the NASEER samples in the northeast monsoon cruise ranging from 12,290-58,214/10 $\mathrm{m}^{2}$ and in the southwest monsoon (cruise 1), copepods were the second most abundant, ranging between 8,600 and 52,474/10 $\mathrm{m}^{2}$ (Amjad et al., 1995).

In all 27 genera and 39 species were identified. Percentages of copepods among all zooplankters was calculated for all of NASEER (I) 32 samples, which was on average $75.30 \%$. The highest value $(93.79 \%)$ was at station $57 \mathrm{~B}$ between the coast of Makran (Pakistan) and Oman coast and the lowest value $(38.45 \%)$ was very near the Oman coast. The four copepod groups showed different distributional patterns. The calanoids were numerically highest (92.09\%) in the central Arabian Sea station (St. 24) during the day and lowest (47.61\%) at station (St. 49) 
opposite to Oman coast. In contrast, the percentage of harpacticoids was highest $(0.70 \%)$ at St. 60 opposite the Makran coast and lowest $(0.02 \%)$ in the central Arabian Sea station (33C) during the day. The cyclopoids were most abundant (15.16\%) at St. 37 and lowest $(0.04 \%)$ near the Makran coast. The poecilostomatoids occurred in their highest percentage (46.78\%) at station 57A (D) and lowest (7.76\%) in the central Arabian Sea. The cyclopoids highest percentage (15.16\%) was at St. 37(N) and lowest at St. $62(0.04 \%)$. A total of 17 families, identified and arranged in order of frequency of occurrence at all stations occupied during NASEER I, are: Paracalanidae, Calanidae, Corycaeidae, Euchaetidae, Oncaeidae, Eucalanidae, Metridinidae, Oithonidae, Pontellidae, Sapphirinidae, Candaciidae, Centropagidae, Acartiidae, Clymnestridae, Ectinosomatidae, Miraciidae, and Temoridae.

\section{DISTRIBUTION OF DIFFERENT SPECIES}

Pleuromamma indica is not uniformly distributed in NASEER samples, maximum at St. 42(D) near Oman coast missing from Sts. 24, 27B, 27C and 53. Goswami et al. (1992) found this species with high densities in the northern Arabian Sea, highest near the India-Pakistan border at Kutch, whereas Razouls (1998) indicated a high density throughout much of the northern Arabian Sea. Saraswathy (1986) suggested that $P$. indica was tolerant of low oxygen concentration (as low as $0.1 \mathrm{ml} \mathrm{L}^{-1}$ ) in the northern Arabian Sea and made up 2195\% of myctophid diet (Saraswathy, 1986; Goswami et al., 1992).

Gaussia swelli is endemic to the northern Indian Ocean particularly in the Arabian Sea and Bay of Bengal (Saraswathy, 1973).

Acartia amboinensis is said to be the most dominant copepod in shelf and slope regions of Pakistan (Haq et al., 1973), a conclusion supported by the processing of the NASEER samples. Acartia hamata was collected for the first time from the northern Arabian Sea (Indian Ocean). This is an extension of range record. The present distribution of Acartia hamata is the Pacific Ocean.

Pontella karachiensis Fazal-ur-Rehman, 1973 is no longer considered endemic to Karachi. Its range now extends to India (Patel, 1975).

Candacia samassae was not encountered in NASEER samples, although it is considered endemic in all waters north of $10^{\circ} \mathrm{N}$ in the Arabian Sea (Razouls, 1998). Pillai (1967) had already pointed out its rarity in the area.

The paracalanid e.g. Paracalanus parvus, is the most abundant species in NASEER samples i.e. $93 \%$ of all the copepods.
The calocalanid Calocalanus pavo was numerically maximum at St. 37. Rhincalanus cornutus is very poorly represented in NASEER samples. This species is equatorial, known from the Atlantic Ocean on one hand and from the Indian and Pacific Oceans on the other. It has been reported that $R$. cornutus is geographically polytypic and actually consists of 2 populations, one restricted to the Atlantic Ocean and the other ranging through the Indian and Pacific Oceans (Fleminger and Hulsemann, 1973). The prevalence of females dominated males in Rhincalanus and Subeucalanus.

The calanids are second highest (31.47\%) among the calanoids but the diversity is low. Undinula vulgaris, present in the samples, is a species of upwelling waters (Razouls, 1998). Different Pakistani genera reacted in different ways to the variation of the oxygen. Species that reacted worst to oxygen deficiencies in the upper layer were Calanus minor, Calanus brevicornis, Acrocalanus gracilis, Lacicutia flavicornis, and Subeucalanus subtenius (Gololobov and Grobov, 1970). The numbers of individuals of the predator genera Oncaea and Oithona and the phytophagus genera (Paracalanus, Acrocalanus and Clausocalanus) were uneven at the nearest-situated stations depending upon the predominance of upwelling (Gololobov and Grobov, 1970).

Species of Oncaea, Corycaeus, Farranula, Copilia and Sapphirina are not common in ONR inshore samples as already noted for the northern Arabian Sea inshore waters of Bombay (Gajbhiye et al., 1991), but some of them like Corycaeus spp. and Oncaea conifera are most common epiplanktonic species from Pakistan offshore waters (Haq et al., 1973). Oncaea and Farranula in NASEER samples were in breeding stages, either as copulated females with spermatophores or with attached egg cases. Oncaea venusta, although free living and pelagic, has been found on fish gills (Kazatchenko and Adeev, 1977) or in a sponge (Ho, 1984) and now from the sand (Kazmi and Naushaba, 2000).

Although six species of Copilia are present in the northern Arabian Sea (Sewell, 1948), only Copilia mirabilis was encountered in NASEER I samples with both morphs present. Sapprinidae is the least abundant family with maximum numbers at St.33D and minimum near the Makran coast (St. 62). Five species of Sapphirina are reported by Sewell (1947) but NASEER I samples had only S. gemma, and another species has yet to be determined.

Oithona plumifera, sole species representing the cyclopoids, had its highest number observed in a night sample at St. 37, which is away from the Pakistan coast. Oithona spp. were dominant (397 individuals $/ \mathrm{m}^{3}$ ) in shelf area (Gololobov and Grobov, 1970). 
Centropages furcatus is present in a patchy pattern in NASEER I samples, with St. 18 having the highest numbers while nearby station (St. 15) had the lowest number. Two temorids were encountered in NASEER samples, one is still unidentified. The genus Temora is found in maximum numbers in the central part of the Arabian Sea. The euchaeitids are the third highest in the NASEER samples, a finding that concurs with Razouls' report (1998) for the Arabian Sea. Euchaeitids' maximum numbers were obtained at a station located in the Indus Cone area.

The eucalanids are present in all samples, though the density pattern is not uniform.

The Ectinosomatidae was most abundant near the Makran coast in night samples (St. 60) and the second highest $(21.71 \%)$ among the harpacticoids in NASEER samples. Clytemnestra scutellata was the most copious $(62.99 \%)$ among the harpacticoids, with the highest number at an off shore station (St. 60) in a night sample. Miracia efferata and Macrosetella gracilis are the least abundant harpacticoids.

It can be concluded that in the NASEER samples the maximum numbers of copepods were present at St. 33D. The calanoids and poecilostomatoids are present in all the samples. When comparisons are made for all the four general groups in samples from NASEER I and NASEER IV, at different stations the prevalence of species is variable. Only females represent most of the taxa as generally is the case, and if males are present, they are smaller than the females. Most of the individuals were adults, few immature copepodid stages were observed.

\section{ONR plankton samples (1993-1995)}

The plankton sample analysis revealed that copepods were generally higher in number at the surface than at the subsurface level of Manora Channel waters. In an earlier study from the same area (Nayeem, 1993) two peaks of copepods were reported. The distribution of copepods in the Manora Channel may be influenced by the circulation water, nutrients and contamination of water since this channel receives a large quantity and variety of effluents from Karachi City through the sewage outfall of the River Lyari and from oil waste discharge. The stratification and stability of the seawater does not allow for vertical mixing (Rizvi et al., 1995).

\section{ONR meiobenthic samples (1998-2000)}

A literature survey indicated that no such type of study had been done before in our coastal areas. During recent years, two different projects for meiobenthic surveys on sandy and backwater mangrove areas respectively, were conducted. The copepod densities in the mangrove area were lower in pre-monsoon and southwest monsoon seasons and were higher with more harpacticoids found in northeast monsoon season (Qureshi and Sultana, 2000).

The difference in the species composition at Bulleji and Sandspit area is due to differences in the beach slopes and distribution of grain size (Fig. 1). The Sandspit is a major recreational attraction for the residents of Karachi. Consequently, this collection site for ONR samples at Sandspid was purposely chosen for its location in the vicinity of a large fishing village (Kakka Village) and hence considerable human pressure was expected. The abundance and diversity of copepods (both adult and larvae) in the coming months may be correlated with the changes of size in sand grains at Sandspit in the months of April and May, with a slight increase in the salinity. The harpacticoids usually dominated the populations. Some species, which are either planktonic or seem to be phytal, were trapped in the sediments. The maximum numbers of copepod larvae were observed in July and adults observed were in September (Fig. 2). Nauplii of Diossacidae were dominant in the sand samples in the month of August.

Parategastes, a phytal genus which was screened out of the sand samples, was surprisingly not reported from the algae by Ghani and Nawaz (2000).

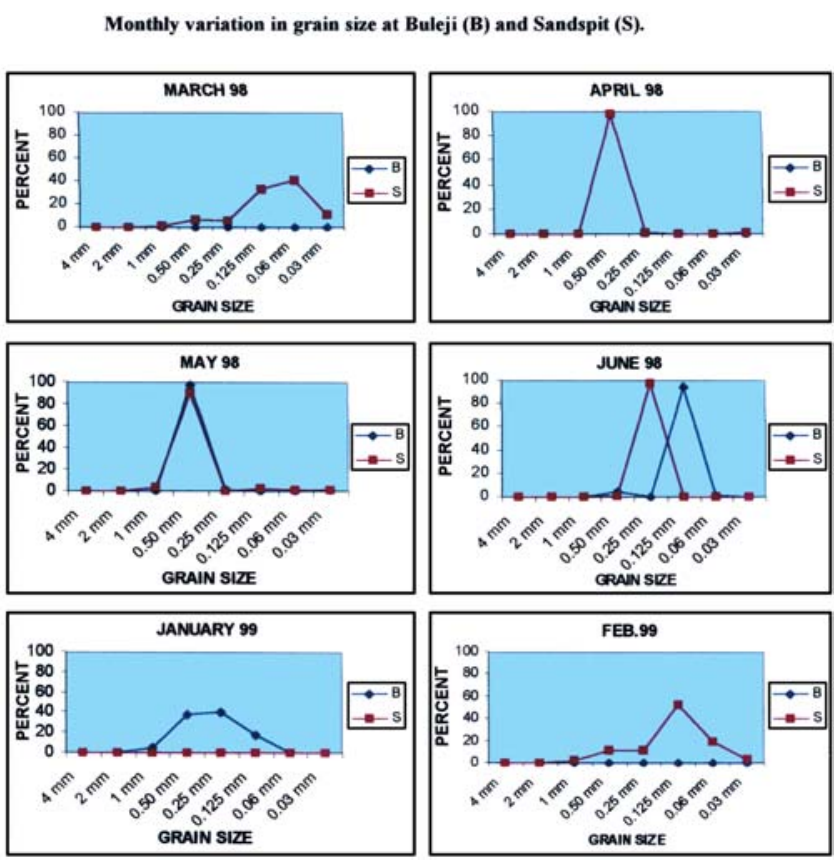

Fig. 1. Monthly variation in grain size at Buleji (B) and Sandspit (S). 


\section{ONR phytal species}

The search for phytal species can be divided into two phases, one from 1993-1995 on the coast and the other from 1998-2000 in the mangrove area of Manora Island near Karachi.

During the first phase copepods were found in associations with Caulerpa racemosa, Galaxura sp., Ulva fasciata, Sargassum swartzi, Laurentia sp., Corallina, Colpomenia, and Hypnea maciformis. The results of 1995 analysis showed that the abundance (\%) of epifaunal copepods among the other epifauna was the highest (43.20\%) on Caulerpa racemosa at Bulleji in April and on Galaxura sp. at Korangi Creek in May (47.05\%), on Ulva fasciata at Pacha $(75.80 \%)$ and on Sargassam swartzi at the same place in November (35.66\%). Sargassam swartzi at Bulleji in the same month had a more or less similar percentage (37.26\%). Laophonte cornuta was collected from Laurentia at Cape Monze, Metamphiascopsis hirsutus from Corallina sp., Laurentia sp. and Hypnea maciformis at Pacha, Porcellidium fimbriatum and Caligus sp. from Corallina, Sargassum, Caulerpa, Colpomenia and Ulva from different localities.

During the second phase, Ulva reticulata and Enteromorpha inestinalis were collected from mangrove area. Copepods were second highest to amphipods in all the samples except those from Enteromorpha
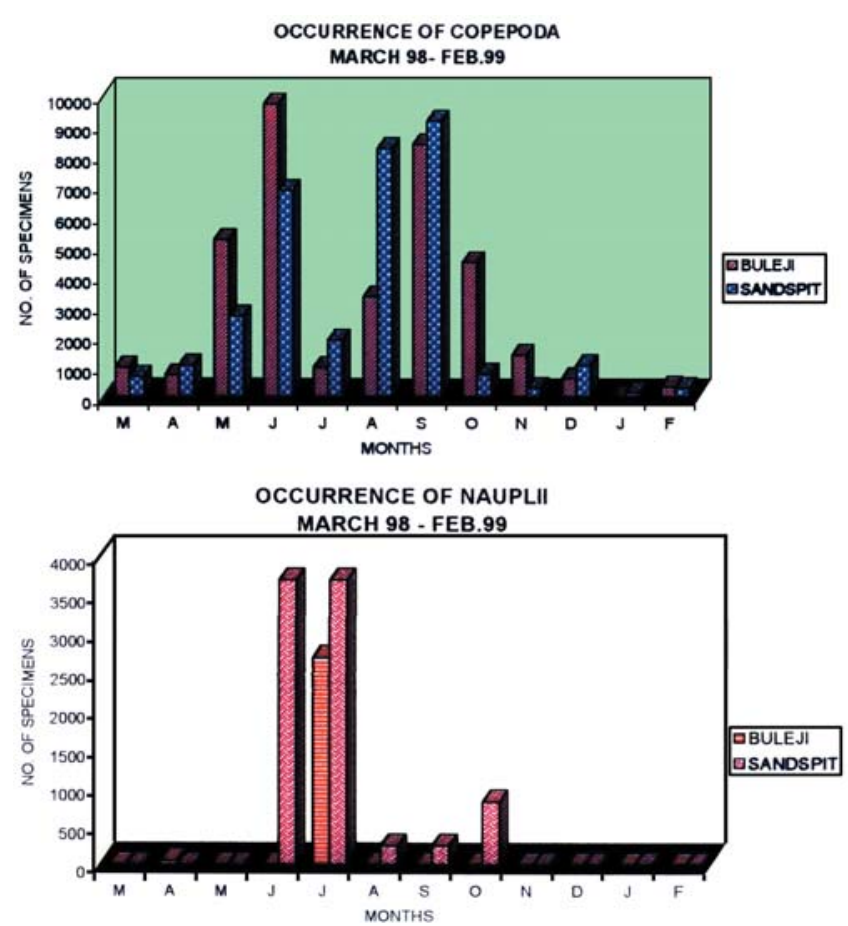

Fig. 2. Occurrence of adult copepods and nauplii collected during March 1988-Feb. 1999 from Buleji and Sandspit. in June, 1999 and January 2000 (Ghani and Nawaz, 2000).

\section{CONCLUSION}

A conclusion can not be drawn regarding the species composition that is different in all the available lists (Sewell, 1948; Gololobov and Grobov, 1970; Ali Khan, 1998; NASEER samples and Razouls' 1998 IND 16). In the present checklist, the taxonomy in Sewell's and Ali Khan's lists has been updated to match Razouls' taxa of 1993. Nevertheless, for many reasons the species compositions are not comparable. For example, most of the available older data from the area under investigation primarily cover the large calanoid copepods of the $0-200 \mathrm{~m}$ strata, thus under-representing the inshore water planktonic and benthic copepods and smaller species. In addition, Soviet research vessels in the Arabian Sea collected throughout the northern and central Arabian Sea but, except for a few reports, the results are either unpublished or written only in Russian and are generally unavailable. Another reason may be that the Arabian Sea is a distinctive pelagic habitat in some respects and as a result there are distinctive hydrographic subregions, as indicated by the uneven distribution patterns of Candacia and Paracandacia (Lawson, 1977). Physical forces, monsoon reversal, and low oxygen levels can influence distribution and species composition.

Because enumeration of the Indian Ocean plankton samples of the entire copepods assemblage from samples collected previously within a defined region and season, has not been done before, the earlier reports leave us ill-prepared to specify with any confidence which copepod species are dominant regionally or seasonally. (taken from www.cbl.umces.edu and usglobec reports).

\section{ACKNOWLEDGEMENTS}

I am grateful to my inspirational teacher Prof. N. M. Tirmizi, then Director of MRC, who obtained NASEER material from NIO, Karachi for me. Dr. Shahid Amjad, Director General NIO, Karachi is thanked for his assistance. This paper was read at $8^{\text {th }}$ International conference on copepod (ICOC) 2002, Taiwan. It is with pleasure I express my gratitude to Dr. Ju-Shey Ho for suggesting my name for ICOC. Thanks are expressed to the organizers of ICOC for financial support that enabled me to join ICOC. Special thanks to Ms. Rene Chang of the conference secretariat for prompt answers and arrangements. Razia Naushaba of MRC helped in meiobenthic collection.

These scientists helped in various ways: Dr. Hans- 
U-Dahms of Oldenburg, Germany for identification of the genus Parategastes and nauplii of Diosaccidae. Drs. Ju-Shey Ho, F.D. Ferrari, S. Vander Spoel, A.D. Mackinnon, C.K. Wong, T.C. Walter, H.B. Michael, G. A. Boxshall, and C. Razouls - who also allowed a free access to websites for confirmation of species, provided necessary literature and valuable suggestions on Muniza's thesis. Razia Naushaba of MRC helped in meiobenthic collection.

Dr. Patsy McLaughlin of Shannon Point, Marine Centre, Western Washington, USA is acknowledged for Rindly improving the text.

\section{REFERENCES}

1. Ahmed, M., "Plankton of Karachi Coast and Their Bearing on Fishes," Agric. Pakistan, Vol. 2, pp. $22-31$ (1951).

2. Ahmed, M.F., Syed, S.M., Karim, S.I., Niazi, M.S., Jawaid, T., and Masihuzzaman, M., "Arthropoda (Marine Fauna Supplement)," Rec. Zool. Surv. Pakistan, Vol. 4, No. 1 and 2, pp. 51-60 (1972).

3. Ahmed, S.I., Amjad, S., and Rizvi, S.H.N., "Pakistan and U.S. Conduct Cooperative Research Program In North Arabian Sea," U.S. JGOFS Newsletter, December, 1993, pp. 13-14 (1993).

4. Ali M. and Arshad, M., "Preliminary Observations on the Composition of Zooplanktons Along Karachi Coast," Agri. Pakistan, Vol. 17, No. 2, pp. 227-237 (1966).

5. Ali Q.M., “A New Record of Parasitic Copepod Paralebion elongatus Wilson, 1911," Proc. Paras., No. 20, pp. 91-93 (1995).

6. Ali Khan, S., "Pelagic Copepods from Pakistani Waters (Arabian Sea) Part I, Family Eucalanidae," Mar. Res., Vol. 1, No. 1, pp. 87-96 (1992).

7. Ali Khan, S., "Pelagic Copepod from Pakistan Waters (Arabian Sea) Part II, Family Euchaetidae," Mar. Res., Vol. 2, No. 1 and 2, pp. 17-23 (1993a).

8. Ali Khan, S., "Two New Records of Heterorhabdidae (Copepoda, Calanoida) from the Arabian Sea off Pakistan," Crustaceana, Vol. 65, No. 1, pp. 120-125 (1993b).

9. Ali Khan, S., "First Record of Benthomisophria palliata Sars, 1909 from the Indian Ocean (Copepoda, Misophriidae)," The 13th Pak. Cong. Zool., Abstract, p. $121(1993 \mathrm{c})$.

10. Ali Khan, S., "Pelagic Copepods from Pakistani Waters (Arabian Sea) Part V, Family Candaciidae," Mar. Res., Vol. 4, No. 2, pp. 147-151 (1995).

11. Ali Khan, S., Easy Identification Sheets. Copepoda: Calanoida F.A.O. Area: 51 Western Indian Ocean (Arabian Sea), CEMB Publication, Planktonology \#1 (Copepoda), University of Karachi, Karachi, Pakistan (1998)
12. Ali Khan, S. and Ali Khan, J., "Seven New Records of the Family Lucicutiidae from Pakistan (Copepoda, Calanoida)," Crustaceana, Vol. 43, No. 3, pp. 265-270 (1982).

13. Ali Khan, S. and Ali, Khan, J., "Nine New Records of the Family Augaptilidae from Pakistan (Copepoda, Calanoida)," Crustaceana, Vol. 47, No. 3, pp. 303-313 (1984).

14. Al-Yamani, F., Ismail, W.A., and Fahmi, A.M., Copepods from Kuwaiti Coastal Waters of the Arabian Gulf, Technical Report, Published by Kuwait Institute for Scientific Research, Mariculture and Fisheries Department, Food Resources Division, pp. 14-33 (1995).

15. Amjad, S., Khan, M.E., Hashmi, M.A., Shah, A.D., and Khan, T.A., "Imapct of Monsoon Reversal on Zooplankton Abundance and Composition in the Northwestern Arabian Sea," Proc. of the Conference on Arabian Sea, Living Marine Resources and the Environment, pp. 499508 (1995).

16. ARABESQUE., "UK Contribution to JGOFS Process Studies of the Arabian Sea," British Oceanographic Data Centre, www.bodc.ac.uk (1994).

17. Bindra, S.S., "Crustacean Plankton from Karachi Harbour,” Proc. Lahore Philosophical Soc., Vol. 3, pp. 78-80 (1924).

18. De Decker, A. and Mombeck, F.J., "South African Contribution to the International Indian Ocean Expedition 4: A Preliminary Report on the Planktonic Copepoda," Invest. Rep. Div. Sea Fish. S. Africa, Vol. 51, pp. 10-67 (1965).

19. Fazal-ur-Rehman, "A New Calanoid Copepod, Pontella karachiensis from W. Pakistan," Crustaceana, Vol. 24, pp. 152-156 (1973a).

20. Fazal-ur-Rehman, "Observation on Variation in a Planktonic Copepod Tortanus forcipatus (Giesbrecht, 1889) from the Inshore Waters of the Karachi Coast, Pakistan". Crustaceana, Vol. 25, No. 2, pp. 113-118 (1973b).

21. Fazal-ur-Rehman, "Nouvelle Description of the Female and a Redescription of the Male Pontella investigatoris (Sewell, 1912) from Inshore Waters of Karachi," Pak. J. Zool., Vol. 6, No. 1 and 2, pp. 105-110 (1974).

22. Fleminger, A. and Hulsemann, K., "Relationship of Indian Ocean Epiplanktonic Calanoids to the World Oceans," Ecological Stidies: Analysis and Synthesis, Vol. 3, Springer-Verlag, Berlin and New York, pp. 339378 (1973).

23. Gajbhiye, S.N., Stephen, R., Nair, V.R., and Desai, B.N., "Copepods of the Nearshore Waters of Bombay," Indian J. Mar. Sci., Vol. 20, No. 3, pp. 187-194 (1991).

24. Ghani, N. and Ali, Q.M., "A Parasitic Copepod Lernaeenicus hemirhamphi Kirtisinghe, 1933 (Copepoda, Siphonostomatoida) on Polynemus sextilis from Arabian Sea," Sci. Khyber, Vol. 90, No. 1, pp. 69-72 (1996a).

25. Ghani, N. and Ali, Q.M., "Morphological Variations in 
Protochondracanthus sp. (Copepoda, Chondracanthidae) from Psettodes erumei (Schneider) from Northern Arabian Sea," Proc. Para., Vol. 22, pp. 25-30 (1996b).

26. Ghani, N. and Nawaz, F., "Fauna Associated with the Weeds of Manora Mangroves," Proc. of the Natl. ONR Symp. on Arabian Sea as a Resource of Biological Diversity, pp. 65-89 (2000).

27. Giesbrecht, W., "Pelagische Copepoden," Beitrage zur fauna Spit. Arch. Nat., Vol. 55, No. 1, pp. 63-165 (1889).

28. Gololobov, J.A. and Grobov, A.G., Summary Account on the Scientific Research Works of the Expedition in the Waters Adjacent to the Islamic Republic of Pakistan (January to December 1969), Azor-Black Sea Research Institute of Marine Fishery and Oceanography, Ministry of Fisheries of the USSR, p. 166 (1970).

29. Gopalakrishnan, T.C. and Balachandran, T., "Northsouth Diversity of Scolecithricidae Species (Copepoda: Calanoida) in the Indian Ocean," Proc. of the Oceanography of the Indian Ocean, pp. 167-175 (1992).

30. Goswami, S.C., "Distribution of Pleuromamma spp. (Copepoda-Calanoida) in the Northern Arabian Sea," Ind. J. Mar. Sci., Vol. 23, No. 3, pp. 178-179 (1994).

31. Goswami, S.C., Gajbhiye, S.N., and Padmavati, G., "Distribution of Pleuromamma (Copepoda: Metridiidae) Along a North-south Transect in the Indian Ocean," Proc. of the Oceanography of the Indian Ocean, pp. 157166 (1992).

32. Grice, G.D. and Hulsemann, K., "Bathypelagic Calanoid Copepods of the Western Indian Ocean," Proc. U.S. Nat. Museum, Vol. 122, No. 3583, pp. 1-67 (1967).

33. Haq, S.M., "Observation on the Variations in Planktonic Copepod Undinula vulgaris (Dana, 1849) from the North Arabian Sea," J. Univ. Karachi, Vol. 5, No. 3, pp. 86-92 (1968).

34. Haq, S.M. and Fazal-ur-Rehman., "A New Calanoid Copepod, Centropages karachiensis from the Inshore Waters of the Karachi Coast, West Pakistan," Zool., Med., Vol. 46, No. 13, pp. 183-188 (1973).

35. Haq, S.M., Ali Khan, J., and Chughtai, S., "The Distribution and Abundance of Zooplankton along the Coast of Pakistan During the Postmonsoon and Premonsoon Periods," Ecological Studies: Analysis and Synthesis, Vol. 3, Springer-Verlag, Berlin and New York, pp. 257272 (1973).

36. Ho, J.S., "Copepoda Associated with Sponges, Cnidarians, and Tunicates of the Sea of Japan," Rep. Sado Mar. Biol. Stat., Niigata Univ., No. 14, pp. 23-61 (1984).

37. Huda, I.A., "Zooplankton Standing Stock and Composition in Coastal Waters of Arabian Sea (Sindh and Makran Coast of Pakistan)," Proc. of the National Semimar on Study and Management of Coastal zones in Pakistan. UNESCO and MRC, Karachi, pp. 121-136 (1993).
38. Kasturirangan, L.R., Saraswathy, M., and Gopalakrishnan, T.C., "Distribution of Copepoda in the Indian Ocean," Ecological Studies: Analysis and Synthesis, Vol. 3, Springer-Verlag, Berain and New York, pp. 331-333 (1973).

39. Kazatchenko, V.N. and Adeev, G.V., "Parasitic Copepods (Crustacea) Collected During 57th Cruise of 'Vityaz' in the Western Tropical Pacific and Seas of the IndoMalayan Archipelago," Trudy Inst. Okeanol., Vol. 107, pp. 30-48 (1977).

40. Kazmi, Q.B. and Muniza, F., "Notes on Two Harpacticoid Copepods (Crustacea) Gathered from Plankton Collection During NASEER Cruise, January 1992 in the Arabian Sea," Proc. Pakistan Congress Zool., Vol. 14, pp. 151-156 (1994).

41. Kazmi, Q.B. and Muniza, F., "Distribution and Abundance of Poecilostomatoid Population of Copepods in NASEER Cruise I, January 1992," The 15 $5^{\text {th }}$ Pakistan Congress of Zoology, Abstract p. 106 (1995).

42. Kazmi, Q.B. and Muniza, F., "Harpacticoid Copepods Collected During Northern Arabian Sea Ecological and Environmental Research (NASEER) Cruise 1 January 1992," The $17^{\text {th }}$ Pakistan Congress of Zoology, Karachi, Abstract 100 (1997a).

43. Kazmi, Q.B. and Muniza, F., "Pelagic Copepods of North Arabian Sea," Proc. of the Biodiversity of Pakistan, PMNH and Florida N.H. Museum, pp. 295-303 (1997b).

44. Kazmi, Q.B. and Muniza, F., "Pleuromamma indica a Metrinid Copepod Collected on the NASEER Cruise 1 in the Arabian Sea," The $18^{\text {th }}$ Pakistan Congress of Zoology, Lahore, Abstract 118 (1998).

45. Kazmi, Q.B. and Naushaba, R., "A Survey of Coastal Marine Interstitial Arthropods from Sandy Area of Karachi," Proc. of the Natl. ONR Symposium on Arabian Sea as a Resource of Biological Diversity, pp. 129-143 (2000).

46. Kazmi, Q.B., Tirmizi, N.M., Ali, Q.M., and Muniza, F., "Preliminary Report on Planktonic Crustaceans of the Arabian Sea Collected by the NASEER Program," Proc. of the Arabian Sea Living Marine Resource and the Environment, pp. 63-76 (1995).

47. Khan, M.A., "Seashore Distribution of Bio-mass and Number of Zooplankton in Manora Channel During 1975-77," Biologia, Vol. 25, pp. 182-203 (1974).

48. Khan, M.A., "Cymbasoma williamsoni sp. nov. (Copepoda-Monstrilloida-Monstrillidae) from Manora Channel (Northern Arabian Sea)," J. Sci., Univ. Karachi, Vol. 4, No. 1 and 2 (1976).

49. Khan, M.A., "New Records of Conchyliurus maximus Reddiah (Cyclopoidea-Clausidiidae) from Sanguinolaria (Soletellina) diphos (Gmelin) from Karachi Coast, Pakistan," Biologia, Vol. 23, No. 1, pp. 95-97 (1977).

50. Khan, M.A. and Kamran, W.M., "Cymbasoma tirmizii 
sp. nov. (Copepoda) from Manora Channel (Northern Arabian Sea)," J. Sci. Univ. Karachi, Vol. 3, No. 1 and 2, pp. 55-59 (1975).

51. Khan, M.A., Kamran, W.M., and Khan, M.F., "Occurrence of Cymbasoma rigidum Thompson (Copepoda, Monstrilloida, Monstrillidae) from Manora Channel (Northern Arabian Sea)," Ag. Pakistan, Vol. 26, No. 1, pp. 113-116 (1988).

52. Lawson, T.J., "Community Interactions and Zoogeography of the Indian Ocean Candaciidae (Copepoda: Calanoida)," Mar. Biol. Berl., Vol. 43, No. 1, pp. 71-92 (1977).

53. Martin, J.W. and Davis, G.E., "An Updated Classification of the Recent Crustacea," Nat. Hist. Mus. Los Angeles County Sci., Ser. 39, pp. 1-24 (2001).

54. Masihuzzaman, M., "On Some Copepods (Calanoids-1) from Korangi Creek, Karachi," Rec. Zool. Surv. Pak., Vol. 5, No. 1 and 2, pp. 51-66 (1973).

55. Muniza, F., "Distribution and Density of Pelagic Copepods Collected by the Northern Arabian Sea Ecological and Environmental Research (NASEER) Cruise in the Northern Arabian Sea," M. Phil. Dissertation, Department of Zoology, University of Karachi, Pakistan (1998).

56. Muniza, F. and Kazmi, Q.B., "Occurrence and Abundance of two Genera: Eucalanus and Rhincalanus of the Family Eucalanidae (Copepoda : Calanoida) in the Sample of NASEER Cruise 1, January 1992," Sci. Int., Lahore, Vol. 7, No. 3, pp. 395-400 (1995).

57. Naushaba, R. and Kazmi, Q.B., "Diversity in Interstitial Fauna at Sandy Beaches, West of Karachi," Workshop, Coastal Zone Management and Environmental Impact Assessment, Higher Education link Programme between the Division of Environmental and Evolutionary Biology. Institute of Biomedical and life Sciences, Glasgow University U.K., and the CEMB, Karachi University, Pakistan, Poster Abstract, p. 40 (1998).

58. Naushaba, R., Kazmi Q.B., and Kazmi, M.A., "Preliminary Study on Meiobenthos on Sandy Beaches of Sandspit and Buleji (Karachi Coast)," The 18th Pakistan Congress of Zoology, Lahore., Abstract, p. 121 (1998).

59. Nayeem, I., Occurrence and Abundance of Zooplankton off Manora Channel During 1989, National Seminar on Study and Management of Coastal Zone, Pakistan. UNESCO, pp. 131-142 (1993).

60. Niazi, M.S. and Ahmed, M.A., "Parasitic Copepods of Marine Fishes of Karachi Coast. Fam: Caligidae," Rec. Zool. Sur. Pakistan, Vol. 5, No. 1 and 2, pp. 79-94 (1973a).

61. Niazi, M.S. and Ahmed, M.A., "Lernaeenicus hemirhamphi Kirt (Lernaeidae: Caligidea), a Copepod Parasite in Hemirhamphus xanthopterus (Val) from Karachi coast," Rec. Zool. Sur. Paksitan, Vol. 5, No. 1 and 2, pp. 7-9 (1973b).

62. NIOP, "The Netherlands Indian Ocean Programme," www.nioz.nl/en/facilities/dmg/niop/niop.htm (1992-93).

63. Patel, M.J., "Pelagic Copepods from the Inshore Waters off Saurastra Coast," J. Mar. Biol. Ass. India, Vol. 17, No. 3, pp. 658-663 (1975).

64. Pillai, P.P.,"On Candacia samassae Pesta, a Rare Calanoid Copepod from the Arabian Sea," J. Mar. Boil. Ass. India, Vol. 9, No. 2, pp. 365-371 (1967).

65. Pillai, P.P., "Post-Naupliar Development of the Calanoid Copepod Temora turbinata (Dana), with Remarks on the Distribution of the Species of the Genus Temora in the Indian Ocean," J. Mar. Boil. Ass. India, Vol. 17, No. 1, pp. 87-95 (1978).

66. Qureshi, N.A., Kazmi, Q.B., and Naushaba, R., "Comparison of Small-scale Spatial Variability of Meiobenthos in Two Different Biotopes Along Karachi Coast, Pakistan," The $2^{\text {nd }}$ Symposium on the Red Sea Marine Environment. Faculty of Marine Science, King Abdul Aziz University Jeddah, Saudi Arabia, Abstract p. 72 (1999).

67. Qureshi, N.A. and Sultana, R., "Distribution and Abundance of Meiobenthos in Sandspit Backwaters Mangrove Area, Karachi," Proc. of the Nat. ONR Symposium on Arabian Sea as Resource of Biological Diversity, pp. 90-103 (2000).

68. Rajaram, L.K. and Krishnaswamy, S., "A Note on the Similarity in the Distribution of Sapphirina (Copepoda, Crustacea) and Salpa (Thaliacea, Tunicata) in the NorthWestern Indian Ocean," Mahasagar, Vol. 13, No. 1, pp. 171-172 (1980).

69. Razouls, C., "Bilan Taxinomique Actuel Des Copepodes Planctoniques Marins et Des Eaux Saumatres," Crustaceana, Vol. 64, No. 3, pp. 300-313 (1993).

70. Razouls, C., "Diversite et Repartirion Geographique Chez Les Copepodes Pelagiques. 1. Calanoida," Ann. Inst. Oceanogr. Paris, (n. ser.) Vol. 71, No. 2, pp. 81-404 (1995).

71. Razouls, C., "Diversite et Repartirion Geographique Chez Les Copepodes Pelagiques. 2. Platycopioida, Misophrioida, Mormonilloida, Cyclopoida, Poecilostomatoida, Siphonostomatoida, Harpacticoida, Monstrilloida," Ann. Inst. Oceanogr. Paris, (n. ser.) Vol. 71, No. 1, pp. 1-149 (1996).

72. Razouls, C., "Essal Sur La Diversite et La Repartition Geographique Chez Les Copepodes Planktoniques Marins. Calanoida, Platycopioida, Misophrioida, Cyclopoida, Poecilostomatoida, Siphonostomatoida, Harpacticoida, Monstrilloida (De 1892 fin 1996)," Webpage Observatoir Oceanologue de Banyuls (1998).

73. Rizvi, S.H.N., Ali Khan, T.M., Ali, S.M., and Baquer, J., "Circulation Patterns in the Karachi Coastal Water in Relation to the Outfall," Proc. of the Seminar on the Arabian Sea Living Marine Resources and the Environment, pp. 641-652 (1995).

74. Sadiq, S. "New Additions in MRC," MRC Newsletter, 
Vol. 4, No. 4, p. 1 (1995).

75. Sadiq, S., "New Additions in Marine Reference Collection and Resource Centre," MRC Newsletter, Vol. 5, No. 1, p. 1 (1996).

76. Saraladevi, K., "Two New Records of Haloptilus (Copepoda: Calanoida) from the Indian Ocean," Proc. of the Symposium on Warm Water Zooplankton, Goa., pp. 41-47 (1977).

77. Saraswathy, M., "Distribution of Gaussia (Copepoda, Metridiidae) in the Upper $200 \mathrm{~m}$ in the Indian Ocean," Ecological Stidies, Analysis and Synthesis, Vol. 3, Springer-Verlag, Berlin and New York, pp. 335-338 (1973).

78. Saraswathy, M., "Pleuromamma (Copepoda: Calanoida) in the Indian Ocean," Mahasagar-Bull. Nat. Inst. Ocean, Vol. 19, pp. 185-201 (1986).

79. Sewell, R.B.S., "The Free Swimming Plankton
Copepoda. Systematic Account," Scient. Rep. John Murray Exped., 1933-34 (Zool.) Vol. 8, No. 1, pp. 1-303 (1947).

80. Sewell, R.B.S., "The Free Swimming Plankton Copepoda, Geographical Distribution," Scient. Rep. John Murray Exped., 1933-34 (Zool.) Vol. 8, No. 3, pp. 317-592 (1948).

81. Stephen, R., Saraladevi, K. Meenkshikunjamma, P.P., Gopalakrishnan, T.C., and Saraswathy, M., "Calanoid Copepods of the International Indian Ocean Expedition Collections," Proc. of the Oceanography of the Indian Ocean, pp. 143-156 (1992).

82. Tirmizi, N.M. and Sadiq, S., "Algae as Habitat Island for Copepods from Two Rocry Areas of Karachi Coast," The 15th Pakistan Congress of Zoology, Abstract No. MB-7, p. 104 (1995). 